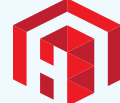 Heighten Science \\ P U B L I C A T I O N S Corporation} ISSN

2577-1469

\title{
Surgical Implantation of Stem Cells in Heart Failure Patients due to Idiophatic Cardiomyopathy
}

\author{
Benetti Federico ${ }^{1 *}$, Natalia Scialacomo ${ }^{1}$, Enrique Mariani ${ }^{1}$, \\ Luis Geffner ${ }^{1}$, Bruno Benetti Eng1 ${ }^{1}$, Daniel Brusich², Yan Duarte ${ }^{3}$ \\ and Ernesto Peñaherrera ${ }^{3}$
}

'Benetti Foundation, Alem 1846 Rosario Santa Fe Argentina Zip 2000, Argentina

${ }^{2}$ Hospital de Clinicas Montevideo, Uruguay

${ }^{3}$ Hospital Luis Vernazza, Guayaquil, Ecuador

*Address for Correspondence: Dr. Benetti Federico, Alem 1846 Rosario Santa Fe Argentina Zip 2000, Argentina, Email:

federicobenetti@hotmail.com

Submitted: 08 July 2017

Approved: 24 July 2017

Published: 25 July 2017

Copyright: @ 2017 Federico B, et al. This is an open access article distributed under the Creative Commons Attribution License, which permits unrestricted use, distribution, and reproduction in any medium, provided the original work is properly cited

Keywords: Stem cells in heart failure patients; Heart failure patients due to Idiophatic Myocadiophaty treat with stem cells; Autologous stem cells in heart failure patients; Embriofetals cells in heart failure patients

Check for updates

\section{ABSTRACT}

Introduction: Congestive heart failure is one of the main causes of morbidity and mortality in the XXI century given the promising to date of ABMDSCs and HFDSCs we investigate the safety and efficacy for the implantation of those stem cells for the treatment of idiopathic cardiomyopathy. This is the first pilot clinical study to assess the safety and feasibility of HFDSC in humans. We totally implanted 13 patients: 3 patients were implanted with ABMDSC by Mini-invasive surgical technique in March 2004 in Montevideo, Uruguay, and 10 patients were implanted with HFDSCs by using 2 different surgical techniques: minimally invasive technique (1 patient) and full sternotomy technique ( 9 patients) between January and February of 2005 in Guayaquil Ecuador.

The HFDSCs were obtained from fetuses of 5 to 12 weeks' gestation from legally consent, no compensated donors who have undergone terminated ectopic pregnancies, elective abortions, or spontaneous miscarriages. At that gestation's period, totipotent stem cells' fetus haven't develop yet the HLA histocompatibility complex, so there's no possible antigenicity between donor and recipient

Results: Patients with HFDSCs improved in association with increased contractility in these regions. Compared with baseline assessments, we noted other improvements: The mean ( \pm SD) NYHA class decreased from $3.4 \pm 0.5$ to $1.33 \pm 0.5(P=.001)$; the mean $E F$ increased $31 \%$, from $26.6 \% \pm 4.0 \%$ to $34.8 \% \pm 7.2 \%(P=.005)$; performance in the ETT increased $291.3 \%$, from 4.25 minutes to 16.63 minutes $(128.9 \%$ in metabolic equivalents, 2.45 to 5.63$)(P<.0001)$; the mean LVEDD decreased $15 \%$, from $6.85 \pm 0.6 \mathrm{~cm}$ to $5.80 \pm 0.58 \mathrm{~cm}(P<.001)$; mean performance in the 6 -minute walk test increased $43.2 \%$, from $251 \pm 113.1$ seconds to $360 \pm 0$ seconds $(P=.01)$; the mean distance increased $64.4 \%$, from $284.4 \pm 144.9 \mathrm{~m}$ to $468.2 \pm 89.8 \mathrm{~m}(\mathrm{P}=.004)$; and the mean result in the Minnesota congestive HF test decreased from $71 \pm 27.3$ to $6 \pm 5.9(P<.001)$ The Kaplan-Maier probability of survival at 48 months was $66 \%$.

It is not observed rejection, these patients have not developed malignance nodules or cancer at all in the follow-up. In the AMBCSs. The preoperative average NYHA functional class was 3.4; at. 6 months of follow up the average functional class value was $1.3(\mathrm{p}<0,005)$;. After 6 months all of them remained in functional class $\mathrm{I} /$ II. Baseline values of LVEF were 25,28 and $30 \%$; at 6 months increased to 38,40 and $46 \%$. $(p<0,05)$. LVESV went from $50 \mathrm{~mm}$ to $42 \mathrm{~mm}(\mathrm{p}<0.05)$. After 24 months, 2 of the patients still maintained this improvement, while the $3^{\text {er }}$ patient returned to the earlier values after suffering from pneumonia. At 12 years and 5 months 2 patients are alive both received a Resynchronization Therapy; at 8 years and 3 months and 9 years and 1,6 month the actual average EF are 28 and $30 \%$. The $3^{\text {er }}$ patient died of sudden death at 10 years after the implantation. We can't demonstrate the cause of this sudden death

Conclusion: Irrespective of the improvement seen in this study, it is still premature to determine accurately the mechanism of action, indications, doses and type of stem cells. Therefore, is imperative and extremely important that more research is needed.

\section{INTRODUCTION}

Congestive heart failure is one of the main causes of morbidity and mortality in the XXI century [1,2]. Patients in advanced stages (NYHA functional classes III/IV) have an average of 5 year survival rates below $50 \%$, with an annual mortality of 40 to $50 \%$ [3], high rates of re hospitalization and elevated costs for the health services 
Etiology for dilated cardiomyopathy is $60 \%$ due to ischemic cardiomyopathy and $40 \%$ of idiopathic-non-ischemic origin.

This category of patients have been managed with medical treatment (ACE inhibitors, diuretics, beta-blockers, and Spiro lactone), ventricular re-synchronization, ventricular assistance and heart transplantation. For many years, heart transplantation has been the surgical treatment of choice for patients with advanced heart failure. This procedure has been successful in many countries; however it presents many limitations, the most important ones being the scarcity of donors and the contraindications of advanced age and severe co-morbid situations [4]. Moreover, there have been frequent deaths during the prolonged periods in the waiting list for organ reception.

The final stage of several heart diseases ending in congestive heart failure is the quantitative deficiency of cardiomyocytes and cardiac remodeling [5]. Reversion of cardiac remodeling lies in the possibility of myocyte regeneration and neovascularization of affected areas. The goal of cellular therapy is the re-population of the myocardium with cells capable of restoring contractility and blood flow: This will improve the systo-diastolic function of the heart. The cells introduced must have the capacity for differentiation into cardiomyocytes or promote revascularization.

Several studies have shown that the adult bone marrow is a rich reservoir of these pluri-potential, mesenchymal stem cells, which contribute to functional neoangiogenesis. They also participate in wound healing and reversion of lower limb ischemia [6], post-MI neo-angiogenesis [7,8], endothelization of vascular grafts [9], atherosclerosis [10], retinal and lymphoid neo-vascularization [11] and vascularization during neo-natal development [12].

Most cell therapy administered to Heart Failure patients to date has been bonemarrow-derived stem cells (ABMDSCs). Embryo Fetal (HFDSCs) stem cells are thought to be more pluripotent than adult stem cells; for example the former can develop into a wider range of specialized cells [13]. Although HFDSCs have been used to treat a variety conditions, including blood and immune system disorders [14], spinal cord injuries [15], stroke [16], other neurologic and eye disorders [17], and diabetes [18], there have been no reports of use of HFDSCs in Heart Failure therapy.

Given the promising to date of ABMDSCs and HFDSCs we investigate the safety and efficacy for the implantation of those stem cells for the treatment of idiopathic cardiomyopathy.

This is the first pilot clinical study to assess the safety and feasibility of HFDSC in humans.

We totally implanted 13 patients: 3 patients were implanted with ABMDSC by Miniinvasive surgical technique in March 2004 in Montevideo, Uruguay, and 10 patients were implanted with HFDSCs by using 2 different surgical techniques: minimally invasive technique ( 1 patient) and full sternotomy technique ( 9 patients) between January and February of 2005 in Guayaquil Ecuador.

The HFDSCs were obtained from fetuses of 5 to 12 weeks' gestation from legally consent, no compensated donors who have undergone terminated ectopic pregnancies, elective abortions, or spontaneous miscarriages.

At that gestation's period, totipotent stem cells' fetus haven't develop yet the HLA histocompatibility complex, so there's no possible antigenicity between donor and recipient. 


\section{METHODS}

This study was performed with the authorization of the Hospital authorities and ethics council; and the patients' informed consent.

The patients presented dilated idiopathic cardiomyopathy with a severe decrease in LVEF and functional capacity.

Inclusion criteria were:

1. Patients in NYHA functional class III/IV.

2. Dilated, idiopathic, non-ischemic and non-chagasic cardiomyopathy with LVEF $<35 \%$.

3. Optimal medical treatment including ACE inhibitors, spironolactone, betablockers and diuretics at an average $85 \%$ of the maximum dose.

4. Bilirubin, creatinine, blood urea nitrogen, serum glucose, glutamine-oxaloacetic transaminase (aspartate aminotransferase), and glutamic-pyruvic transaminase level $<2.5$ times normal values.

5. Symptomatic condition despite of optimal drug therapy for HF.

Exclusion criteria were:

1. Congestive heart failure decompensated in the last 6 days.

2. Cancer present during the last 5 years.

3. Presence of hematological diseases.

4. Leukocyte count above 12000 /cc or below $5000 /$ cc.

5. Renal failure requiring hemodialysis.

6. Previous cardiac surgery.

7. Valvar heart disease requiring surgery.

8. Preoperative steroid therapy.

9. Infectious disease.

10. Blood disease.

11. Diagnosis of epilepsy

12. Positivity in Human Immunodeficiency Virus or venereal Disease Research Laboratory testing.

13. Intolerance or hypersensitivity to biological substances.

14. Participation in another clinical trial.

15. Have a history of drug or alcohol abuse.

16. Psychiatric disturbances.

17. Suicide attempts in the previous 2 years.

18. Renal failure needing dialysis.

19. Pulmonary thromboembolism within the previous 6 months.

20. Mechanical ventilation support within the previous 10 days.

21. Morbid obesity. 
Patients who were initially included but who non-compliant with the protocol (tests or treatment), were lost to follow-up, or developed an unrelated new illness were excluded from the study.

For each patient, preoperative medications (digoxin, furosemide, spironolactone, angiotensin-converting enzyme inhibitors, angiotensin receptor blockers, betablockers) were maintained throughout the study and the follow-up.

\section{STEM CELL EXTRACTION AND PROCESSING}

\section{Bone marrow stem cells}

Patients were taken to the Operating Room monitored, anesthetized and placed in the prone position. Bone marrow (BM) was harvested by hematologists from the iliac crests as is habitually done in the hematology and hemotherapy departments; bilaterally between both posteriors spine. Using this technique we were able to harvest 500 to $600 \mathrm{~mL}$ of bone marrow with a minimally number of puncture sites and were placed in a special container with $10000 \mathrm{U}$ of heparin and acetylsalicylate lysine to prevent coagulation. At least $250 \mathrm{~mL}$ of bone marrow must be harvested to continue with the protocol. The bone marrow was filter followed by a 200-um filter. The resulting solution was centrifuge at $400 \mathrm{~g}$ for $15 \mathrm{~min}$. the cellular pellet was re suspended in phosphate-buffered saline (PBS). The cell solution was mixed 3:1 with a solution of $155 \mathrm{moll} / \mathrm{L} \mathrm{NH}_{4} \mathrm{Cl}$ and $0.1 \mathrm{moll} / \mathrm{L}$ EDTA and set for $15 \mathrm{~min}$ at room temperature. The solution was then centrifuge at $400 \mathrm{~g}$ for $10 \mathrm{~min}$. The pellet was washed with PBS and re suspended. The cell suspension was placed over Ficoll-Paque (1.077 density) 4:1 and centrifuged at $400 \mathrm{~g}$ for $30 \mathrm{~min}$. the upper layer was aspirated, leaving the mononuclear cell layer at the interphase. The interphase cell were transferred to a new conical tube with PBS and centrifuged at $300 \mathrm{~g}$ for $10 \mathrm{~min}$. The supernatant was completed removed, and the cell pellet was re suspended in PBS. Cell counts were performed, and magnetic labeling with Isolex 300i was performed as per standard protocol for peripheral blood progenitor cell products to obtain an enriched product of, at least, $70 \%$ CD34+ cells. The resulting cell solution is re suspended in $30 \mathrm{cc}$ of the patient own serum and $10000 \mathrm{U}$ of heparin sulfate. Cell viability is established with a standard Trypan blue exclusion.

\section{Human fetal-derived stem cells}

Stem Cells HFDSCs were provided by the Institute for Regenerative Medicine, Barbados, and were processed and prepared by the Institute for Problems of Cryobiology and Cry medicine (IPCC) (Kharkov, Ukraine). The IPCC obtains HFDSCs from fetuses of 5 to 12 weeks' gestation from legally consenting, noncompensated donors who have undergone terminated ectopic pregnancies, elective abortions, or spontaneous miscarriages. The HFDSCs are prepared from harvested fetal liver tissue under sterile conditions and undergo polymerase chain reaction testing for human immunodeficiency virus, hepatitis B and C, mycoplasma, toxoplasmosis, cytomegalovirus, and herpes simplex viruses I and II, rubella, and Treponema pallidum; HFDSCs also undergo culture tests for bacterial and fungal contamination. Cell preparations are stored in cry preservatives at $-196^{\circ} \mathrm{C}$ in liquid nitrogen. The percentage of viable cells before thawing was $60 \%$ according to the IPCC certification.

The IPCC shipped HFDSCs in minishipper containers in a cryopreserved state $\left(-150^{\circ} \mathrm{C}\right.$ to $\left.-196^{\circ} \mathrm{C}\right)$ to Luis Vernazza Hospital in Guayaquil Ecuador for this study, and they were maintained in this state until use. Just before the procedure, HFDSCs were thawed at room temperature. In 9 patients, the cells were diluted in $80 \mathrm{~mL}$ of saline solution at $37^{\circ} \mathrm{C}$; in 1 patient, who underwent the procedure via a mini thoracotomy approach, the cells were diluted in $15 \mathrm{~mL}$. Patients received $7.5 \times 10^{5} \mathrm{cells} / \mathrm{mL}$ and $5.3 \times 10^{6}$ cells $/ \mathrm{mL}$, respectively. So in total they received $60-80 \times 10^{6}$ HFDSCs. 


\section{SURGICAL TECHNIQUE}

\section{Sternotomy}

9 patients underwent a midline sternotomy (Figure 1), prior to the injections, 80 marks $(1 \mathrm{~cm}$ apart) were made with a blue methylene marker on the anterolateral, posterolateral, and diaphragmatic left ventricular walls and on the anterolateral right ventricular wall, avoiding coronary blood vessels. We administered 80 injections of $1 \mathrm{~mL}$ each in the marked areas. The injections were made $3 \mathrm{~mm}$ deep with a 25-gauge needle and a catheter. During the procedure, patients were monitored for arterial pressure, central venous pressure, urine output, electrocardiogram, oxygen saturation, and end-tidal carbon dioxide concentration in the expired air. Infusions of potassium (20mEq/hour) and magnesium (1 g/hour) were started before the operations and maintained up to the time of chest closure. All patients were extubated in the operating room.

\section{Minimally Invasive}

3 patients received Autologous Bone Marrow Stem Cells and 1 Human FetalDerived Stem Cells by this approach. After harvesting the ABMDSCs patient is placed in a right lateral position with a $30^{\circ}$ to $45^{\circ}$ inclination from the horizontal plane of the right hemi thorax.

Video-assisted surgery includes positioning of three $10 \mathrm{~mm}$ trocars in the $3^{\text {rd }}, 5^{\text {th }}$ and $7^{\text {th }}$ intercostal spaces: One for the camera and the rests for the instruments. We used a double-lumen ore-tracheal tube in this procedure, and the trocars are introduced once the left lung has been collapse. The camera is inserted posteriorly in the $7^{\text {th }}$ space (Figure 2).

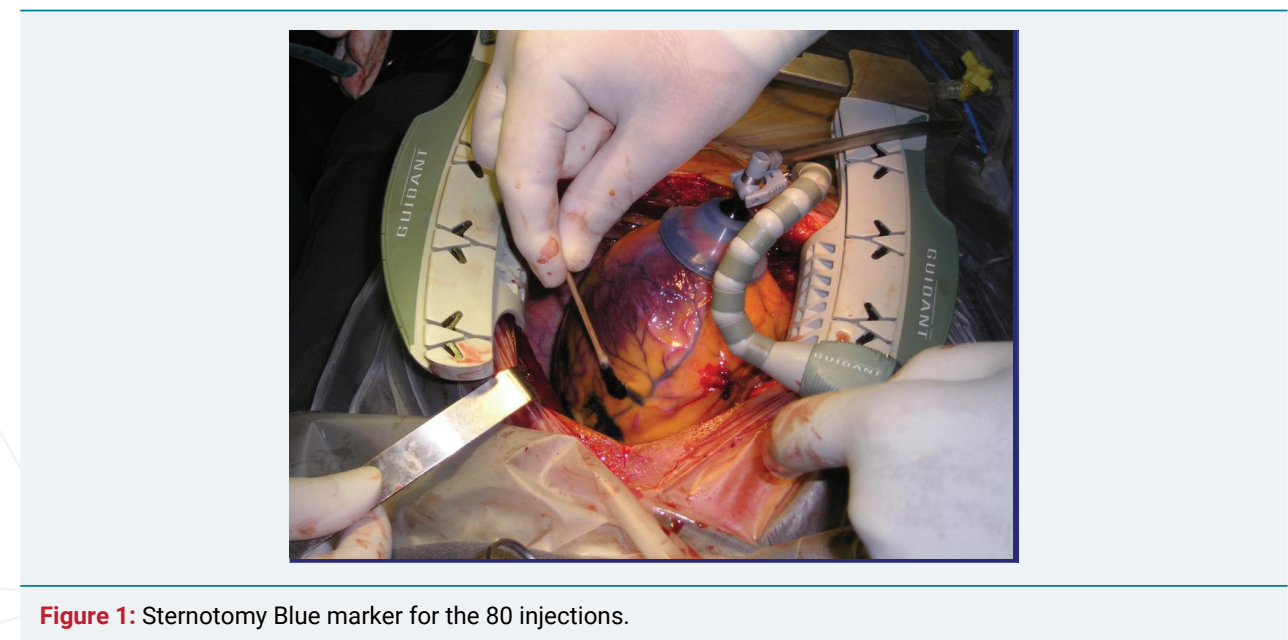

Figure 1: Sternotomy Blue marker for the 80 injections.

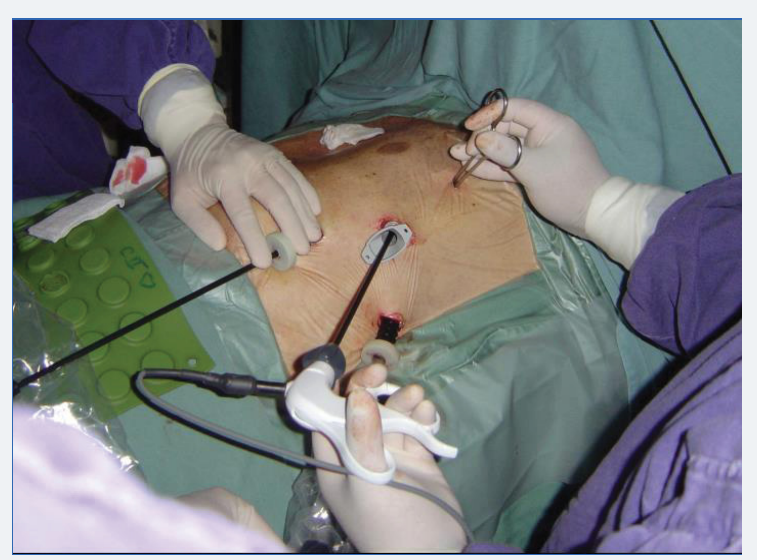

Figure 2: Minimally Invasive Approach for Stem Cells Implantation. 
Exploration begins by opening the pericardium anteriorly to the position of the phrenic nerve. Injection in the selected areas is performed, guided by the preoperative echocardiogram and avoiding intraventricular and intracoronary injection. We deliver aliquots of $1 \mathrm{cc}$ separated by 2 to $3 \mathrm{~cm}$ and 3 to $5 \mathrm{~mm}$ in depth with a $25 \mathrm{G}$ needle with an average of 25 injections in the ABMSCs patients (Figure 3). Only 15 injections were made in the anterolateral wall in the patient who underwent HFDSCs.

The procedure is completed when trocars are withdrawn and the thoracic tube is put in place. Finally, the 4 patients were extubated and leave the OR.

Follow-up are conducted by clinical examination, EKG, X-ray films and echocardiogram at 48 months Results were analyzed by independent cardiologists, not involved in this study.

Statistical analysis applied the student test (SPSS program), with $\mathrm{p}<0.05$ were considered significant.

\section{RESULTS}

\section{Human Fetal-Derived Stem Cells}

6 female and 4 male patients (age range, $47-77$ average 58 years) met the inclusion criteria and participated in the study. 9 of those received HFDSCs by sternotomy and 1 minimally invasive left approach. There was not operative or perioperative mortality.

One male patient (U.J., 69 years) experienced a single transient intraoperative ventricular fibrillation during the procedure but before receiving injections; the ventricular fibrillation was terminated by electrical cardioversion. One man (M.J., 66 years) and 1 woman (V.M., 77 years) required temporary pacemakers postoperatively because of severe bradycardia ( $<40 \mathrm{bpm}$ ), for 24 hours and 48 hours, respectively. The former patient received dobutamine for 24 hours. He also had a mild pericardial effusion at 3 weeks, which resolved spontaneously. He was later excluded from the trial for noncompliance (he abandoned his controls), and he ultimately died at 5 months. The heart autopsy showed nests of cardiomyocytes among the fibrotic tissue, (Figure 4 ), but it was not possible to determine whether they were new growing myocardium or remaining native fibers .One female patient died suddenly at 8 months by severe gastroenteritis complications; the female patient who underwent her procedure via minimally invasive died at 12 months from Heart Failure caused by mitral insufficiency. She had refused a mitral valve operation; another female patient died at 18 months for diabetes complications. The HFDSCs patients who provided 48 months of follow-up data demonstrated improvements both clinically and in imaging studies. With regard to the imaging studies, we noted an increased wall thickness, both eccentric and concentric; patients improved contractility in these regions.

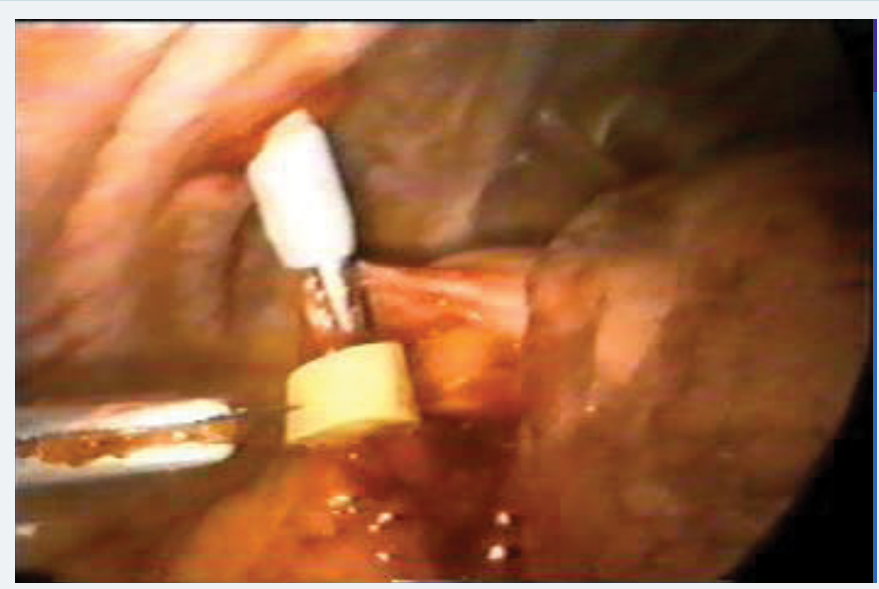

Figure 3: Stem Cells Injection in the Heart by Minimally Invasive Approach. 


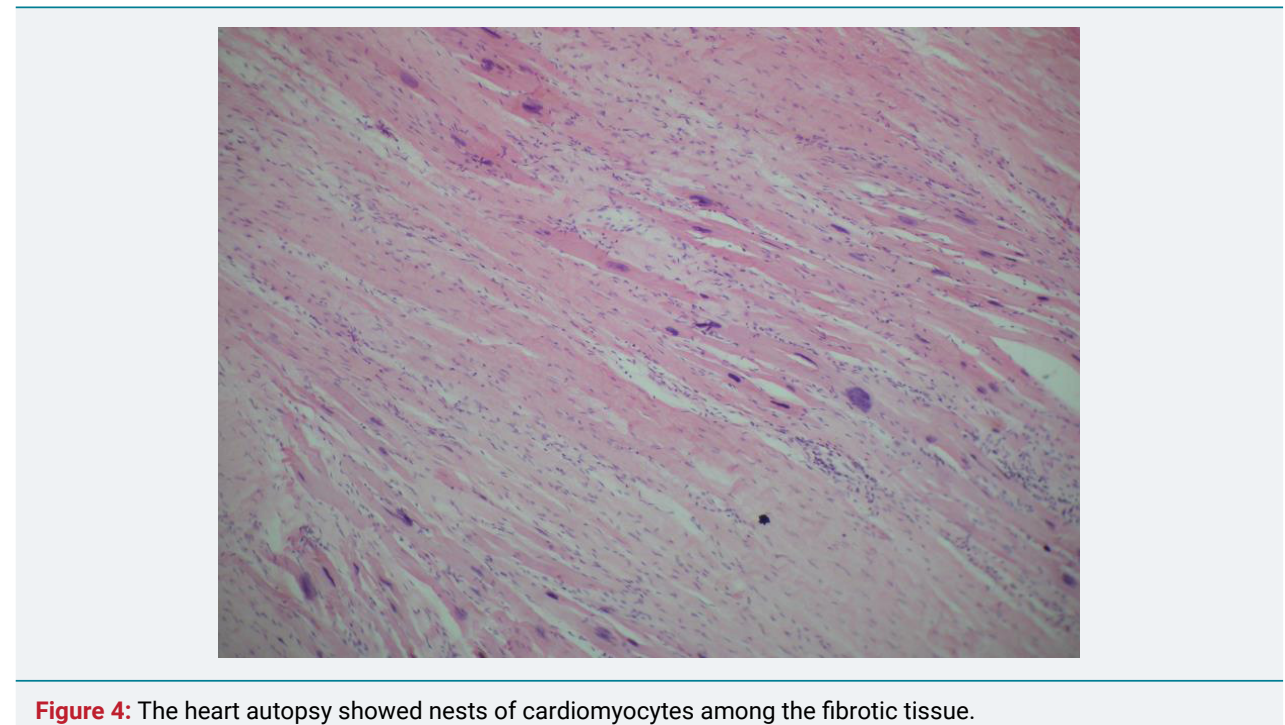

Figure 4: The heart autopsy showed nests of cardiomyocytes among the fibrotic tissue.

Compared with baseline assessments, we noted other improvements: The mean $( \pm$ SD) NYHA class decreased from $3.4 \pm 0.5$ to $1.33 \pm .5(\mathrm{P}=0.001)$; the mean EF increased $31 \%$, from $26.6 \% \pm 4.0 \%$ to $34.8 \% \pm 7.2 \%(\mathrm{P}=0.005)$; performance in the ETT increased $291.3 \%$, from 4.25 minutes to 16.63 minutes (128.9\% in metabolic equivalents, 2.45 to 5.63) $(\mathrm{P}<0.0001)$; the mean LVEDD decreased $15 \%$, from $6.85 \pm 0.6 \mathrm{~cm}$ to $5.80 \pm 0.58 \mathrm{~cm}$ $(\mathrm{P}<.001)$; mean performance in the 6 -minute walk test increased $43.2 \%$, from $251 \pm 113.1$ seconds to $360 \pm 0$ seconds $(P=0.01)$; the mean distance increased $64.4 \%$, from $284.4 \pm 144.9 \mathrm{~m}$ to $468.2 \pm 89.8 \mathrm{~m}(\mathrm{P}=0.004)$; and the mean result in the Minnesota congestive HF test decreased from $71 \pm 27.3$ to $6 \pm 5.9(\mathrm{P}<0.001)$ The Kaplan-Maier probability of survival at 48 months was $66 \%$.

It was not observed rejection; these patents have not developed malignance nodules or cancer at all in the follow-up. The controls were stooped at 48 months One patient died at 11 years due Heart Failure One patient was alive and asymptomatic at 12 years, the rest were lost in the follow up.

\section{AUTOLOGOUS BONE MARROW STEM CELLS}

3 patients, 2 males and 1 woman (age range 62-71 average 67.6 years), fulfilled inclusion criteria and received autologous stem cells by minimally invasive left approach. All patients were extubated in the OR. The pleural tube was withdrawn after $24 \mathrm{hrs}$ and they were discharged after an average of 2.26 days. No complications were observed they received an average of $54 \times 10^{6} / \mathrm{mL}$ CD34+ cells. The preoperative average NYHA functional class was 3.4; at. 6 months of follow up the average functional class value was $1.3(\mathrm{p}<0,005)$; after 6 months all of them remained in functional class I/II. Baseline values of LVEF were 25, 28 and $30 \%$;; At 6 months increased to 38, 40 and $46 \%$ ( $p<0.05)$. LVESV went from $50 \mathrm{~mm}$ to $42 \mathrm{~mm}(\mathrm{p}<0.05)$. After 24 months, 2 of the patients still maintained this improvement, while the $3^{\text {er }}$ patient returned to the earlier values after suffering from pneumonia. At 12 years and 5 months 2 patients are alive both received a Resynchronization Therapy; at 8 years and 3 months and 9 years and 1,6 month the actual average EF are 28 and $30 \%$. The $3^{\text {er }}$ patient died of sudden death at 10 years after the implantation. We can't demonstrate the cause of this sudden death

\section{DISCUSSION}

Stem cells treatments depend not only in the type of cell to be used but also on the way of approaching the target organ or tissue. It is known that intravascular injections of cells rapidly clear from the target vessel. On the other hand it is also well known 
that the direct injection into the myocardium provides better engagement within the cardiac muscle. Therefore, either in case of HFDSC or ABMSC we focused in direct approaches.

When we have to deal with different stimuli, such as parietal stress or direct myocardial injury leading to hemodynamic overload, the heart responds with hypertrophy, capable of initially compensating loss of function. Later on, and for a long sub-clinical period, progressive dilatation continues to be compensated by varying degrees of hypertrophy. At the final stage, as described by Meerson et al [19], dilatation exceeds hypertrophy and changes in cellular organization appear, such as: 1) Myofibrillar lysis; 2) Increase in lysosomes; 3) Distortion of the sarcoplasmic reticulum; 4) substitution of myocardial cells by fibrous tissue.

Simultaneously, capillary density and contractile reserve decrease, and diffuse myocyte necrosis is a feature of both idiopathic and ischemic dilated cardiomyopathy $[20,21]$.

Therefore, idiopathic dilated cardiomyopathy can be described from a pathologic point of view [22], as a dilated heart with hypertrophied walls; macroscopically dilatation exceeds hypertrophy. Microscopically the heart appears invaded by areas of interstitial and perivascular fibrosis, adjacent to necrotic areas and myocytes which may be atrophic or hypertrophic, with loss of the extracellular matrix. Cellular therapy in these patients is directed to restore and repopulate the myocardium, and thus recover the lost function by the delivery of cells that are able to differentiate into myocardial cells.

The use of mesenchymal or stromal cells as precursors of non-hemopoietic tissues was attempted for the first time by the German pathologist Conheim in 1867 [23]. It was later shown in tissue cultures that they were capable of forming diverse tissues, such as bone, cartilage, muscle, ligaments, tendons, etc [23,24], and of intervening in tissue repair [23]. An extremely interesting study showed that stromal stem cells treated with 5 Azacytidine and injected with the cardiomyocytes interconnected with the latter after one week, forming micro-tubule. ;after 2 weeks they start beating and this contraction becomes synchronous after three weeks they develop natriuretic peptide and are stained with antibodies against actin and myosin, and present an action potential of cardiac cells [25].

The trans-differentiation into the cardiac phenotype requires an adequate microenvironment. Dependence on cellular interconnection by generating cardiac transcription factors (GATA-4 and myocyte factor 2 was also observed) [26]. This also was confirmed by other researchers, stressing the importance of cardiomyocyte intercellular integration with trans-differentiated cells [27]. Among the various cell types studied, stromal stem cells were shown to present the capacity for differentiation into muscular and vascular cells, and for producing neo-vascularization. The first reported case of AMBSCs cells applied to a patient was by Weisel and Lee of Toronto University in 1999 [28].

The differentiation into myogenic lineage with development of actin, myosin and tropomyosin was proved, as well as the presence of Conectin 43, a protein responsible of cellular inter-connection.

Several mechanisms of stem cell that work improving cardiac function have been proposed:

1. Fusion and Tran's differentiation: Fusion with local cells has been ruled out; and the attractive concept of stem cells trans-differentiating and crossing the barrier has still to be demonstrated. Perhaps the correct anatomical mechanism will be clarified when cell therapy can be used as a bridge for heart transplantation and biopsies can be performed. 
2. Cardiac stem cell mobilization: Another theory proposes that the implanted cells mobilize specific cardiac stem cells lodged in the muscle that are capable of cardiac regeneration.

3. Angiogenesis: The implanted cells induce significant angiogenesis; according to some, this would be the main mechanism involved.

4. Extracellular matrix: In heart failure there is a net loss of myocytes plus a loss of matrix architecture, which leads to dilatation. The implanted cells could stabilize the latter, preventing dilatation and balancing generation/degradation enzymes. This is the mechanism thought to cause Chagas disease [29].

Clinical application of this treatment was started in 2000, and cases have increased throughout the world. Our study on cases of idiopathic dilated cardiomyopathy shows this is a feasible procedure that have not surgical or immediately postoperative mortality.

This technique has shown extremely good results in prospective, randomized studies in ischemic patients, taken to the OR for myocardial revascularization: Marked improvement was observed in ventricular ejection fraction and functional class in those receiving stem cells compared with those submitted to revascularization alone $[30,31]$. Clinical benefits were evident in improvement of functional class, and no negative effects could be seen.

Patients receiving autologous cell therapy obtained a significant increase in LV ejection fraction immediately and improve the clinical condition.

We recognize that the relatively small number of patients may represent a significant limitation of this study. These initial findings suggest, however, that HFDSC transplantation improves cardiac function in Heart Failure patients due to idiopathic cardiomyopathy. No rejection reactions or malignancy has been seen at 48 months [32].

We believe that the sustained effect of HFDSC therapy indicates that it offers another possibility for treating patients with advanced Heart Failure and represents a new approach that could be used before other major surgical treatments, including heart transplantation, by having them available "on the shelf,": thereby avoiding the time-consuming procedures of autologous bone marrow harvesting and processing. Irrespective of the improvement seen in this study, it is still premature to determine accurately the mechanism of action, indications, and doses. Therefore, is imperative and extremely important that more research is needed.

\section{Statistics}

Data were analyzed with the Statistical Package for Social Sciences (SPSS, Version 15.0).

\section{REFERENCES}

1. Remme WJ, Swedberg K. (co-chairman) Task force for the diagnosis and treatment of chronic heart failure, European Society of Cardiology. Guidelines for the diagnosis and treatment of chronic heart failure. European Heart Journal. 2001; 22: 1527-1560.

2. ColucciW, Braunwald E. Patophysiology of Heart Failure, en Heart Disease de Braunwald. 5a Edición. 1997; 360-393.

3. Enrique V. Carbajal, MD, Prakash C. Deedwani A. Current Diagnosis and Treatment is Cardiology $2^{\text {nd }}$ Ed. Congestive Heart Failure. 2003; 18.

4. Bolling SF, Pagani FD, Deeb GM. Intermediate-term outcome of mitral reconstruction in cardiomyopathy. J Thorac Cardiovasc Surg. 1998; 115: 381-386. Ref.: https://goo.gl/geKzeF

5. Wang JS, Shum-Tim D, Galipeau J, Chedrawy E, et al. Marrow stromal cells for cellular cardiomyoplasty feasibility and potential clinical advantages. J Thorac cardiovasc Surg. 2000; 120: 999-1005. Ref.: https://goo.gl/Jo188c 
6. Rafii S, Lyden D. Therapeutic stem and progenitor cell transplantation for organ vascularization and regeneration. Nat Med. 2003; 9: 702-712. Ref.: https://goo.gl/Kc6RFi

7. Orlic D, Kassutra J, Chimenti S, Jakoniuk I, Anderson SM, et al. Bone marrow cells regenerate infracted myocardium. Nature 2001, 410: 701-705. Ref.: https://goo.gl/2Cp3yv

8. Edelberg JM, Tang L, Hattori K, Lyden D, Rafi S. Young adult bone marrow-derived endothelia precursor cells restore aging-impaired cardiac angiogenic function. Circ Res. 2002; 90: 89-93. Ref.: https://goo.gl/Zs9skw

9. Shi Q, Rafi S, Wu MH, Wijelath ES, Yu C, et al. Evidence for circulating bone marrow-derived endothelial cells. Blood. 1998; 92: 362-367. Ref.: https://goo.gl/jkEvzJ

10. Sata M, Saiura A, Kunisato A, Tojo A, Okara S, et al. Hematopoietic stem cells differentiate into vascular cells that participate in the pathogenesis of atherosclerosis. Nat Med. 2002; 8: 403-409. Ref.: https://goo.gl/FXaqQG

11. Otani A, Kinder K, Ewalt K, Otero S, Tokuhisa T, et al. Bone marrow derived stem cells target retina astrocytes and can promote or inhibit retinal angiogenesis. Nat Med. 2002; 8: 1004-1010. Ref.: https://goo.gl/f6kA4G

12. Young PP, Hofling AA, Sands MS. VEGF increases engraftment of bone marrow-derived endothelia progenitor cells (EPCs) into vasculature of newborn murine recipients. Proc Natl Acad Sci USA. 2002; 99: 11951-11956. Ref.: https://goo.gl/sybF7H

13. O’Donoghue K, Fisk NM. Fetal stem cells. Best Practice residential clinical Obstetric-Gynecologist. 2004; 18: 853-875.

14. Touraine JL. Induction of the transplantation tolerance in humans using stem cells transplants prenatally or postnatally. Transplant Proc. 1999; 31: 2735-2737. Ref.: https://goo.gl/RVwoJr

15. Tsymbalyuk VI, Yaminsky YY. Usage of embryonic nerve tissue transplantation to improve the conductivity of spinal cord after traumatic damage in animals and humans. Transplant ology. 2003; 4: 199-201.

16. Zorin MO, Yurchenko TN, Latyshev DY. Application of cryopreserved suspension of embryonic neural cells in combined treatment of patients with ischemic insults of basal ganglia. Transplant ology. 2003; 4: 149-150

17. Salogub TV. Perspective of embryonic cell transplantation when treating patients wth epileptiform neuralgia of peripheral genesis. Transplant ology. 2003; 4: 184-185.

18. Grischenko VI, Bobirova LE, Dvornek IL, Bovirova VM. Use of biotechnology in treatment of type diabetes. Transplant ology. 2003; 4: 16-19.

19. Meerson FZ. The myocardium in hyperfunction, hypertrophy and heart failure. Circ Res. $1969 ; 25$. Ref.: https://goo.gl/ZVNtdb

20. Zak R. Cardiac hypertrophy: biochemical and cellular relationships. Hosp Pract. 1983; 18: 85-97. Ref.: https://goo.gl/hcm5Eh

21. Prosper F, Pérez A, Merino J, Gregorio Rábago, Juan Carlos Chachques, et al. Adult stem cells for myocardial repair. Basic Appl Myol. 2003; 13: 15-22. Ref.: https://goo.gl/meu43g

22. Colucci WS, Braunwald E. Pathophysiology of heart failure in Braunwald“"s Heart Disease $5^{\text {th }}$ edition Saunders company 1997.

23. Prokop D. Marrow Stromal cells as Stem Cells for no hematopoietic tissues. Science. 1997; 276: 71-76. Ref.: https://goo.gl/eFLtnm

24. Pittenger MF, Makay A, Beck SC, Jaiwasal RK, Douglas R, et al. Multiline age potential of adult human mesenchymal stem cells. Science. 1999; 284: 143-147. Ref.: https://goo.gl/ewfT67

25. Makino S, Fukuda K, Miyoshi S, Konishi F, Kodama H, et al. Cardiomyocytes can be generated from marrow stromal cells in vitro. J Clin Invest. 1999; 105: 697-705. Ref.: https://goo.gl/zkqWyN

26. Xu M, Wani M, Dai YS, Wang J, Yan M, et al. Differentiation of bone marrow stromal cells into cardiac phenotype requires intracellular communication with myocytes. Circulation. 2004; 110: 2658-2665. Ref.: https://goo.gl/5AS3NP

27. Chedrway EG, Wang JS, Nguyen DM, shum-Tim J, Chiu RCJ. Incorporation and integration of implanted myogenic and stem cells into native myocardial fibers: anatomic basis for functional improvements. J Thorac Cardiovasc Surg. 2002; 124: 584-590. Ref.: https://goo.gl/TsAqpV 
28. Pittenger MF, Bradley JM. Mesenchymal stem cells and their potential as cardiac therapeutics. Circulation research. 2004; 95. Ref.: https://goo.gl/KCja9d

29. Vilas-Boas F, Soares G, Sooare MB, Joel Alves Pinho-Filho; Augusto Mota, et al. Bone marrow cell transplantation to the myocardium of a patient with heart failure due to Chagas disease. Arq Bras Cardiol. 2004; 82: 185-187. Ref.: https://goo.gl/4vGjTx

30. Benetti F, Viña RF, Patel AN. OPCABG plus simultaneous autologous stem cells implants. 2003.

31. Patel AN, Geffner L, Vina RF, Jorge Saslavsky, Harold Urschel C, et al. Surgical treatment for congestive heart failure with autologous adult stem cell transplantation: A prospective randomized study. J Thorac Cardiovasc Surg. 2005; 130: 1631-1638. Ref.: https://goo.gl/jXCi51

32. Benetti $F$ MD, Peñherrera E, Maldonado T, Vera YD, Subramanian V, et al. Direct Myocardial Implantation of Human Fetal Stem Cells in Heart Failure Patients: Long-term Results. The Heart Surgery Forum. 2010; 13: 31-35. Ref.: https://goo.gl/QsA7Lu 